DEMOGRAPHIC RESEARCH

VOLUME 37, ARTICLE 37, PAGES 1245-1274

PUBLISHED 19 OCTOBER 2017

http://www.demographic-research.org/Volumes/Vol37/37/

DOI: 10.4054/DemRes.2017.37.37

Research Article

Social policies, separation, and second birth spacing in Western Europe

Michaela Kreyenfeld

Esther Geisler

Teresa Castro Martín

Tina Hannemann

Valerie Heintz-Martin

Marika Jalovaara
Hill Kulu

Silvia Meggiolaro

Dimitri Mortelmans

Inge Pasteels

Marta Seiz

Anne Solaz

This publication is part of the Special Collection on "Separation, Divorce, Repartnering, and Remarriage around the World," organized by Guest Editors Benoît Laplante and Andrew Cherlin.

(C) 2017 Michaela Kreyenfeld et al.

This open-access work is published under the terms of the Creative Commons Attribution 3.0 Germany (CC BY 3.0 DE), which permits use, reproduction, and distribution in any medium, provided the original author(s) and source are given credit.

See https://creativecommons.org/licenses/by/3.0/de/legalcode/ 


\section{Contents}

1 Introduction 1246

2 Prior research 1248

3 Social policy, demographic context, and hypotheses 1249

$\begin{array}{lll}3.1 & \text { Social policy context } & 1249\end{array}$

3.2 Demographic context 1252

3.3 Hypotheses 1253

$4 \quad$ Data and method 1254

$5 \quad$ Results 1257

$\begin{array}{lll}5.1 & \text { Separation and birth spacing } & 1257\end{array}$

$\begin{array}{lll}5.2 & \text { Multivariate results } & 1261\end{array}$

5.3 Transition to second births in new unions 1262

6 Discussion and limitations 1264

7 Acknowledgments 1266

$\begin{array}{ll}\text { References } & 1267\end{array}$

$\begin{array}{ll}\text { Appendix } & 1272\end{array}$ 


\title{
Social policies, separation, and second birth spacing in Western Europe
}

\author{
Michaela Kreyenfeld ${ }^{1}$ \\ Esther Geisler $^{2}$ \\ Teresa Castro Martín ${ }^{3}$ \\ Tina Hannemann ${ }^{4}$ \\ Valerie Heintz-Martin ${ }^{5}$ \\ Marika Jalovaara ${ }^{6}$
}

\author{
Hill Kulu ${ }^{7}$ \\ Silvia Meggiolaro ${ }^{8}$ \\ Dimitri Mortelmans 9 \\ Inge Pasteels ${ }^{10}$ \\ Marta Seiz ${ }^{11}$ \\ Anne Solaz ${ }^{12}$
}

\begin{abstract}

\section{OBJECTIVE}

This paper studies postseparation fertility behavior. The aim is to investigate whether, and if so how, separation affects second birth spacing in Western European countries.
\end{abstract}

\section{METHODS}

This analysis makes use of rich survey data from Belgium, France, Germany, Italy, Spain, and the United Kingdom, as well as from Finnish register data. We thus cover the behavior of a large proportion of the population of Western Europe. We also use descriptive measures, such as Kaplan-Meier survival functions and cumulative incidence curves. In the multivariate analysis, we employ event history modeling to show how education relates to postseparation fertility behavior.

\footnotetext{
${ }^{1}$ Hertie School of Governance, Berlin, Germany. E-Mail: Kreyenfeld@hertie-school.org.

${ }^{2}$ Hertie School of Governance, Berlin, Germany.

${ }^{3}$ Centro de Ciencias Humanas y Sociales, Consejo Superior de Investigaciones Científicas, Madrid, Spain.

${ }^{4}$ Cathie Marsh Institute for Social Research, University of Manchester, UK.

${ }^{5}$ Deutsches Jugendinstitut, Munich, Germany.

${ }^{6}$ Department of Social Research, University of Turku, Finland.

${ }^{7}$ School of Geography and Sustainable Development, University of St Andrews, UK.

${ }^{8}$ Department of Statistical Sciences, University of Padova, Italy.

${ }^{9}$ Faculty of Political and Social Sciences, University of Antwerp, Belgium.

${ }^{10}$ PXL Social Work-Research, Hogeschool PXL, Hasselt, Belgium.

${ }^{11}$ Sociology II (Social Structure) Department, Universidad Nacional de Educación a Distancia, Madrid, Spain.

${ }^{12}$ Institut National d'Etudes Démographiques, Paris, France.
} 


\section{RESULTS}

There are large differences in postseparation fertility behavior across European countries. For Spain and Italy, we find that only a negligibly small proportion of the population have a second child after separating from the other parent of the firstborn child. The countries with the highest proportion of second children with a new partner are the United Kingdom, Germany, and Finland. In all countries, separation after first birth leads to a sharp increase in the birth interval between first and second births.

\section{CONTRIBUTION}

Our study is a contribution to the demographic literature that aims at understanding birth spacing patterns in Western Europe. Furthermore, we draw attention to the role of postseparation policies in explaining country differences in fertility behavior in contemporary societies.

\section{Introduction}

There is a large body of literature that examines the role of social policies in fertility behavior in contemporary societies (e.g., Castles 2003; Gauthier 2007; McDonald 2000; Kalwij 2010; Wood 2016). Great emphasis has been laid on the effect of childcare services, such as the availability of places in public childcare institutions (e.g., Kravdal 1996). The role of parental leave regulations for fertility transition and birth spacing has also been examined (e.g., Duvander, Lappegard, and Andersson 2010). In the same vein, comparative welfare state research has highlighted the role of childcare and parental leave in explaining country differences in total fertility. A common view in this context is that many of the fertility differences in contemporary Europe can be explained by country differences in family and work reconciliation policies (Castles 2003). Countries that are unable to reform their family policies and instead adhere to the "housewife model" would experience low birth rates (Esping-Andersen 1999).

Although this literature has greatly advanced our understanding of social policies and fertility changes, it remains incomplete to some extent. Comparative welfare state research has largely focused on work and family reconciliation policies, while the rules and regulations that govern postseparation behavior have not been considered with the same degree of enthusiasm. In the demographic literature, a large body of research exists that examines postseparation behavior. Here, however, country differences in behavior are rarely explained by social policies. With our paper, we seek to bridge these two strands of literature by exploring the relationship between postseparation policies and postseparation fertility behavior. 
Our study relates to the large body of demographic literature that deals with the fertility behavior of stepfamilies in individual countries (Beaujouan and Wiles-Portier 2011; Heintz-Martin, Le Bourdais, and Hamplová 2014; Henz 2002; Holland and Thomson 2011; Meggiolaro and Ongaro 2010; Vikat, Thomson, and Hoem 1999) and in a crossnational context (see, e.g., Henz and Thomson 2005; Thomson 2004; Vikat, Thomson, and Prskawetz 2004). It is also linked to research that has investigated multipartnered fertility - that is, the question of whether men and women have children with different partners across their life courses (Carlson and Furstenberg 2006; Guzzo and Furstenberg 2007a, 2007b; Manlove et al. 2008; Scott et al. 2013; Thomson et al.2014). Unlike prior studies, our paper focuses specifically on second birth spacing and, as a corollary, the transition to the second biological child after union disruption. We focus on second birth behavior because having a second child is quite a regular and predictable event. Most people in Western Europe aspire to have two children (Testa 2007). Those who have a second child tend to do so around two to four years after the first birth. There are several reasons given in the literature for this close spacing of first and second children. Ní Bhrolcháin (1986) argues that close spacing of births is an efficient way of organizing the fertility career because it minimizes fertility-related employment interruptions. Others refer to the "sibling hypothesis" to explain a rapid progression to the second child (Griffith, Koo, and Suchindran 1985; Henz 2002). According to this hypothesis, one of the underlying motivations in industrialized societies for having two children is to provide a companion for the firstborn child. A close spacing of births guarantees that the two first children can grow up and play together during their childhood years and have a close relationship during their teenage years and into adulthood.

Whatever the reasons for the close spacing of first and second children may be, separation after first birth has considerable consequences for the fertility careers of individuals. First-time mothers and fathers who experience union dissolution after a first birth see not only a breakdown of their partnership, but also a potential disruption of their fertility careers. The questions of how union dissolution influences second birth spacing and how the impact varies by education and national policy context are the main themes of this investigation. Data for our analysis comes from recent survey and register data for Belgium, Finland, France, Germany, Italy, Spain, and the United Kingdom. We thus focus on Western European countries and do not (with the exception of eastern Germany) study fertility behavior in postsocialist countries. The reason for this is that the particularities of fertility behavior in Central and Eastern European countries after the demise of their socialist systems would require a separate investigation beyond the scope of this paper. 


\section{Prior research}

There is extensive research on individual European countries (Beaujouan and WilesPortier 2011; Heintz-Martin et al. 2014; Henz 2002; Holland and Thomson 2011; Meggiolaro and Ongaro 2010; Vikat et al. 1999), as well as work done from a comparative perspective (see, e.g., Henz and Thomson 2005; Thomson 2004; Vikat et al. 2004), that has addressed the fertility behavior of stepfamilies. In this type of research, stepfamilies are commonly defined as a family formed by a man and a woman who live in a coresidential union with a child or with children where at least one of the partners has children from a prior partnership. This research examines whether individuals in stepfamilies behave differently from individuals in families that have only shared biological children. One popular hypothesis is that the fertility of stepfamilies is elevated because couples try to cement their (new) relationship with a common child (Thomson 2004: 118). This union commitment explains why stepfamilies generally have an above-average family size of three or more children (Holland and Thomson 2011; Kreyenfeld and Martin 2011; Martin 2008). Stepfamily research has greatly advanced our understanding of family diversity in contemporary societies. However, the disadvantage of this approach is that it starts the observation with the formation of a stepfamily. One consequence is that nonunion births are commonly disregarded.

A related body of literature has approached the issue by using the individual fertility career as a point of departure. Carlson and Furstenberg (2006) coined the term "multi-partnered fertility" in this context to illustrate the fact that men and women may have children with different partners across their life courses. This strand of research has a strong motivation rooted in social policy concerns over the inability of men with low levels of education to pay child support for children they have fathered with different women. Empirical evidence from the United States has indeed shown a strong negative educational gradient in multi-partnered fertility. Black men and women with less education, as well as those who have their first children in their teenage years, are prone to have children with different partners (Carlson and Furstenberg 2006; Guzzo and Furstenberg 2007a, 2007b; Manlove et al. 2008; Scott et al. 2013). Evidence from Europe on this topic remains sparse, but a comparative study for Australia, the United States, Norway, and Sweden which addressed the likelihood of women having a second or third child with a new parent also finds a strong and negative educational gradient in multi-partnered fertility in the Nordic countries of Europe (Thomson et al. 2014). Gałęzewska (2016) used data for Estonia, France, Norway, Russia, and the United Kingdom to study the fertility transition after the dissolution of the first fertile union. She finds some educational differences for Estonia, but no significant differences by level of education for the other countries. 
Our study is closely linked to the above-mentioned studies, but unlike prior research we focus more narrowly on the spacing between the first and second children. We take a life course perspective in order to gain a better understanding of the consequences of separation for the timing and spacing of subsequent life course events. More specifically, we ask whether separation has affected second birth spacing across Europe and if so how this pattern varies by education and social policy context.

\section{Social policy, demographic context, and hypotheses}

\subsection{Social policy context}

Social policy regulations may favor one family form over another by defining the benefits and constraints involved in leaving the parental home, moving in with a partner, getting married, or having children (Gauthier 2007). In this vein, authors of comparative welfare state literature have emphasized the role of family policies, in particular the availability of childcare and parental leave regulations, for family dynamics in Europe (Castles 2003; McDonald 2000; Neyer 2003; Thévenon 2011). The term "familialism" describes the underpinning of social policies that assign "maximum care duties" to the family (Esping-Andersen 1999). Typical for familialistic regimes are low maternal full-time employment rates, a gendered division of care work, and the economic dependence of women with children on the male breadwinner. Defamilialization describes social policies that work in the opposite direction and enable both women and men to be employed and economically independent. Gender equality in the labor market and a fair division of family duties - typical for a defamilializing system - are expected to be conducive to fertility in advanced economies. Conversely, familialistic regimes are viewed as being counterproductive for fertility, because they overburden the family with care obligations (Esping-Andersen 1999).

Familialism also determines the family behavior after separation and divorce. In general, union dissolution has the most consequences in familialistic welfare state regimes, where the gender division of household chores was the most unequal before divorce and separation (Burkhauser et al. 1991; Andreß and Bröckel 2007; Bröckel and Andreß 2015). Because public childcare is unavailable and because women have often been absent from the labor market for a significant amount of time, they have limited possibilities to enter the labor market after the breakdown of a union. Countries differ, however, in respect of whether they expect the economically weaker party to be gainfully employed or whether he or she can rely on spousal support. These policies buffer the negative consequences of a marital breakdown for the weaker party in a 
familialistic regime. Spousal support may, however, impose a significant economic burden on the economically stronger party, which may inhibit his or her ability to form a family with a new partner. It may also discourage repartnering after divorce for the person who receives the payments, because spousal support can be curbed when a new coresidential union is formed.

In the past, most countries had divorce laws in place that provided support for the financially weaker ex-spouse. ${ }^{13}$ However, there are large differences across Western Europe. In addition, many countries have reformed their divorce laws recently, enabling a swifter divorce process and reducing access to spousal support.

Germany used to be among the countries with the most generous maintenance regulations for the "caring" ex-spouse. Divorced women (and in theory also men) were generally not expected to be employed full-time until the youngest child reached age 16 (Lenze 2014). A reform in 2008 introduced the concept of individual responsibility. The legal requirement to pay spousal maintenance to the caring ex-partner is limited now until the youngest child is age 3 . However, legislation is vague and spousal support for divorcees with older children can still be granted based on individual court cases. If no employment can be found despite intensive search, divorcees are usually granted spousal support. Unlike in Finland (see next paragraph), divorcees do not have immediate access to social benefits. The assumption is that the marital bond extends beyond the breakdown of a union; in the case of need, the ex-spouse must step in and provide support.

Finland is positioned at the other end of the spectrum, with divorce basically considered a clean break with very limited financial obligations between former spouses. In principle, Finnish law provides the possibility to claim maintenance after divorce. However, such claims do not materialize because of high female employment rates. In addition, social benefits are considered in the calculation of potential payments, so that spousal maintenance does not come into effect. This is in stark contrast to Germany, where spousal support extends beyond marital breakdown.

As in Finland, the guiding principle in the United Kingdom is personal responsibility after divorce. ${ }^{14}$ The difference is, however, that social security benefits the claimant could receive are not taken into account in determining maintenance. Furthermore, English and Welsh divorce law has been described as very generous to the

\footnotetext{
${ }^{13}$ Apart from spousal support, there are also differences in other postseparation regulations. All countries considered in our investigation have some regulations in place that define child support payments for the nonresident parent. However, countries differ in their willingness to enforce these regulations (see Table A-3 in the Appendix). Some differences also exist in respect to physical custody regulations, with Belgium being at the forefront of shared physical custody (see Table A-4 in the Appendix). However, in the other countries the proportion of postseparation families practicing shared physical custody is much lower. In most countries children reside with the mother after separation.

${ }^{14}$ In the United Kingdom, all four national regions have their own divorce laws. Since we cannot describe all of them in detail, we concentrate on England and Wales.
} 
economically weaker spouse, and only modest pressure is put on the receiving exspouse to find employment (Klett-Davies 2016). It is only recently that court practice has changed, with the expectation that women who had previously not been employed or had worked reduced hours should increase their employment after divorce.

The situation is ambivalent in France. It is the one country that still holds on to the principle of fault-based divorce. The partner who is claimed to be guilty for the breakdown of the marriage may be excluded from receiving spousal alimony. This seemingly harsh and outdated regulation is, however, not very significant. Fault-based divorce applies to only a very small proportion of all divorces. Moreover, spousal alimony, in contrast to child alimony, is infrequent and, if granted, very low. According to Boisson and Wisnia-Weill (2012), spousal alimony was granted in just $10 \%$ of all divorces. As in Finland, spouses are assumed to be economically independent before and after divorce.

A similar approach is taken by the divorce law of Belgium. It was only in 2007 that fault-based divorce was abolished. Although it is possible to claim spousal maintenance, individual responsibility is emphasized in Belgian law. As female fulltime employment rates are generally high, the expectation is that both parties will be employed after divorce. One aspect that distinguishes Belgium from the other countries is the residence of the children. Unlike in the other countries, children do not necessarily live with the mother after divorce (see Table A-4 in the Appendix). Instead, shared physical custody is very widespread. As a consequence of the more equal division of care after divorce, divorcees cannot claim spousal support easily on the grounds of their care obligations.

The case is very different for Spain and Italy. Here, female employment rates are comparatively low, a strongly gendered division of work exists, and therefore the possibilities for mothers to be economically independent are limited. Despite being familialistic in nature, there is no functioning system of spousal support that buffers the economic consequences of a marital breakdown for the weaker party. Divorced women are more likely than divorced men to stay in the family home after divorce. However, only about $12 \%$ of divorcees in Spain and $20 \%$ in Italy receive financial support from their ex-partners (Instituto Nacional de Estadística (INE) 2013; ISTAT 2014). It is consistent with the principles of a familialistic regime to ameliorate the adverse consequences of divorce for the economically weaker party through spousal alimony payments. As this is not the case in Italy and Spain, divorce poses a significant economic risk for the weaker party (Ongaro, Mazzuco, and Meggiolaro 2009; Andreß et al. 2006). Economic dependence may hinder the weaker party from leaving a union and thus curbs the freedom to leave "potentially oppressive relationships" (Orloff 1993: 320). If people nevertheless decide to end a marriage, strict divorce laws that demand long separation periods are an obstacle to entering a new partnership and to having 
children with a new partner. It was only in 2015 that Italy relaxed its regulations, and couples are now allowed to divorce after one year of separation in cases of mutual consent.

\subsection{Demographic context}

In addition to the pivotal role of institutional contexts, it is also vital to acknowledge that fertility decisions are embedded in the larger logic of the life course. The term "life course contingency" was coined in this context to highlight the path dependency of life course decisions (Hogan 1978). Prior life course events determine the subsequent life course. They may open up new behavioral options or close them. For postseparation fertility behavior, past decisions on whether to marry or cohabit can be influential for subsequent life course outcomes, because spousal support is commonly granted to divorcees only. The countries we consider for our investigation differ greatly in terms of marriage behavior and nonmarital childbearing. In Finland and France, a large proportion of births are out of wedlock. In Italy, only a smaller proportion of births are nonmarital. In 2012, this applied to $26 \%$ of all births (compared to $42 \%$ in Finland, $57 \%$ in France, and 48\% in the United Kingdom) (EUROSTAT 2015). Nonmarital childbearing in Spain sky-rocketed to almost $40 \%$ in 2012. Germany is an interesting intermediate case because of the stark differences in nonmarital parenthood between eastern and western Germany: in 2012, more than $60 \%$ of all births were nonmarital in the east, compared to $28 \%$ in the west.

In order to understand postseparation birth behavior, it is particularly important to know about the separation and divorce patterns in a country. Unfortunately, there is a lack of suitable and comparable official indicators. Most statistical offices generate the crude divorce rate, but separations are not recorded in the vital registration system. Furthermore, the number and age of children are not systematically accounted for in the divorce statistics; if anything is recorded, it is only the number of children who are minors. As a consequence, we have no comparable data from the vital registration system to tell us at which point in the childbearing process separation or divorce occurs.

In the absence of comparable official data, Table 1 maps separation statistics that are based on our own calculations (the data source is explained in more detail in Section 4). The table includes data on Belgium, Finland, France, Italy, Spain, and the United Kingdom. Because of the stark differences in demographic behavior, figures for eastern and western Germany are reported separately. The table lists the probability of being separated from the other parent of the firstborn child. The process time is the age of the first child. All unions are included here, regardless of whether they were marital or nonmarital. Also people who had a child outside of any coresidential partnership are 
included (they are coded as if they separated at the birth of the child). As depicted in this table, large differences in separation probabilities of parents exist across Western European countries. In Finland, eastern Germany, and the United Kingdom, about 15\% of those men and women who had children were not in a union with the mother or father any longer when the first child was born. By the time the first child reached age 10 , the proportion of separated parents had increased to nearly a quarter. In western Germany, France, and Belgium, only a small proportion of people have a first child outside a union. Separation probabilities increase thereafter. However, when the first child is 10 years old, between $10 \%$ and $15 \%$ of the parents are separated. In Southern Europe, the proportion is smaller: only 10\% in Spain and 6\% in Italy. From this, one must conclude that the proportion of the population which is subject to the risk of having a second child after separation differs greatly across countries.

Table 1: Proportion of women and men who had a first child and are separated, by age of first child and country ${ }^{15}$

\begin{tabular}{lcccccccc}
\hline Age of first child & Belgium & Finland & France & $\begin{array}{c}\text { Germany } \\
\text { (western) }\end{array}$ & $\begin{array}{c}\text { Germany } \\
\text { (eastern) }\end{array}$ & Italy & Spain & United Kingdom \\
\hline Birth of child & $7 \%$ & $14 \%$ & $5 \%$ & $8 \%$ & $16 \%$ & $5 \%$ & $8 \%$ & $16 \%$ \\
Age 5 & $10 \%$ & $17 \%$ & $8 \%$ & $11 \%$ & $20 \%$ & $5 \%$ & $9 \%$ & $20 \%$ \\
Age 10 & $13 \%$ & $23 \%$ & $12 \%$ & $14 \%$ & $27 \%$ & $6 \%$ & $10 \%$ & $24 \%$ \\
Individuals & 1,844 & 20,488 & 2,054 & 2,134 & 535 & 7,028 & 1,666 & 13,576 \\
Separations & 268 & 5,313 & 269 & 309 & 164 & 426 & 141 & 3,224 \\
\hline
\end{tabular}

Notes: The sample includes women and men who had their first child in 1990 or later. For Germany only cohorts born 1971-1973 and for Finland only cohorts born 1969-1972 were selected for this representation. The Spanish sample includes women only.

Results for Belgium, Germany, and France were weighted.

\subsection{Hypotheses}

The following investigation explores how separation shapes second birth behavior in Belgium, Finland, France, Germany, and the United Kingdom. We treat eastern and western Germany separately because of the large differences in marriage behavior, women's work patterns, and separation probabilities of one-child parents.

The most important reason why we expect to find country differences in the prevalence of second births in new unions is the country differences in separation behavior. For Italy and Spain, we expect to observe a small proportion of second children in new unions. People do not enter the risk set of having a child with a new partner because they rarely dissolve a union. By this logic, France, Belgium, and

15 Table A-2 in the Appendix complements this table by providing estimates of the competing risk of separation and having a second child. It supports the perspective of Table 1 in that many couples in the United Kingdom, Finland, and eastern Germany separate before having a second child. 
western Germany hold an intermediate position, while the United Kingdom, Finland, and eastern Germany are extreme cases, with high proportions of people at risk of having a child in a new union.

Beyond these demographics, social policies have an impact on postseparation behavior. They may do so by inhibiting divorce, as is the case in Italy and Spain. They may also affect repartnering, as is the case in Germany and England and Wales, where the weaker partner loses spousal support when they enter a new coresidential union, while the stronger party is burdened with economic payments to the ex-partner. Countries such as Finland, Belgium, and France, which support women's (and men's) economic independence, generally offer a clear break after divorce that facilitates entrance into a new partnership and the transition to a new child in a new union.

Apart from the country differences, we also examine differences by level of education. Here we test whether the findings for the United States can be transferred to European countries. For the United States, a strong negative educational gradient in multi-partnered fertility has been reported in various studies. This has raised a social policy concern, in particular because poorly educated men were often unable to pay alimony after separation and divorce. Unfortunately, this part of the investigation must be limited to Finland, western Germany, and the United Kingdom, because the sample size for the other countries is too small for an in-depth analysis by educational level.

\section{Data and method}

To answer our research questions, we use recent survey data for Belgium, France, Germany, Italy, Spain, and the United Kingdom (see Table A-1 in the Appendix for an overview). For Finland, we use data drawn from national population registers. The analyses were conducted separately for each country by the respective national representatives. However, we have tried to harmonize the analyses as much as possible by providing a data manual that describes in detail how union and fertility histories were cleaned and how missing information was imputed in the different national data sets (see core code in the Online Appendix). Due to the different sources of data available to us, some country particularities persisted. For example, the Spanish sample includes female respondents only.

Our sample is limited to respondents who have at least one biological child. Respondents with multiple births were deleted from the sample. Because our interest is in more recent behavior, we limited the investigation to men and women who had their first children after 1990. For Germany and Finland, where the data follows a cohort design, we have restricted the analysis to women and men born around 1970 (19691973 for Finland and 1971-1973 for Germany). Our key interest is in the birth spacing 
between first and second births and whether a person has a second child in a new union. For Germany and Finland, it is possible to link children and unions and to clearly identify whether a second child is from a new parent who is not the father or mother of the firstborn child. As this information is not available from the other data sources, however, we decided to harmonize the procedure for all countries. We follow a strategy that is commonly applied in stepfamily research (Holland and Thomson 2011). Accordingly, we assume that the second child is with a new partner if the woman or man experienced a separation or divorce between the births of the first and second children or entered a new coresidential union during this time. Some couples may have children outside of any union and only subsequently form a joint household. Our strategy would erroneously classify the second children as births with a new partner. To reduce this potential misclassification, we assume that a person who moved in with a partner within six months of the first birth had already been living with that particular partner at first birth. Some women and men may have first and second children as single parents. Others may be single at first birth and have the second child in a coresidential union. In these cases we assume that the children are from different partners.

As a first step, an extensive descriptive analysis presents easily accessible measures which depict the interrelation of separation and second birth spacing patterns. We calculate the mean differences between first and second births and distinguish the cases by whether the second child is in an ongoing union or not. Furthermore, we employ cumulative incidence curves (Gooley et al. 1999) to estimate the probabilities of having a second child in an ongoing union versus the probabilities of having a child in a new union. The multivariate analysis consists of an event history model that studies the determinants of second birth progressions. The key independent variable is the union status. We distinguish episodes in "ongoing unions," in the status of being "single," and episodes in "new unions." People who are still partnered with the same person as when the first child was born are classified as ongoing unions. People who no longer live with the same person as when the first child was born are assumed to be in a new union. The process time in our model is the age of the first child modeled as a piecewise-constant function. We also control for the parent's age at first birth (categorized) and sex. Furthermore, we include a categorical variable for highest level of education achieved up to the date of the interview. We distinguish low education (ISCED97 1-2), medium education (ISCED97 3-4), and high education (ISCED97 56). Table 2 provides the number of occurrences and exposures for the different countries and the respective variables. Note the low exposure population in a new union for Italy and Spain. 
Kreyenfeld et al.: Social policies, separation, and second birth spacing in Western Europe

Table 2: Occurrences (occ.) and exposures (\% exp.) for the multivariate model (see Table 3)

\begin{tabular}{|c|c|c|c|c|c|c|c|c|}
\hline & \multicolumn{2}{|c|}{ Belgium } & \multicolumn{2}{|c|}{ France } & \multicolumn{2}{|c|}{$\begin{array}{l}\text { Germany } \\
\text { (western) }\end{array}$} & \multicolumn{2}{|c|}{$\begin{array}{l}\text { Germany } \\
\text { (eastern) }\end{array}$} \\
\hline & Occ. & $\%$ exp. & Occ. & $\%$ exp. & Occ. & $\%$ exp. & Occ. & $\% \exp$. \\
\hline \multicolumn{9}{|l|}{ Age of first child } \\
\hline Age $0-1$ & 386 & 39 & 284 & 46 & 492 & 41 & 80 & 32 \\
\hline Age 2-3 & 540 & 21 & 759 & 26 & 1,005 & 24 & 165 & 23 \\
\hline Age 4-5 & 143 & 12 & 245 & 12 & 345 & 13 & 100 & 15 \\
\hline Age 6-7 & 38 & 8 & 82 & 7 & 115 & 8 & 58 & 11 \\
\hline Age 8-9 & 23 & 6 & 27 & 4 & 52 & 5 & 30 & 7 \\
\hline Age 10 and older & 9 & 13 & 5 & 5 & 53 & 8 & 17 & 12 \\
\hline \multicolumn{9}{|c|}{ Respondents' age at first birth } \\
\hline Age $15-21$ & 95 & 7 & 143 & 9 & 451 & 23 & 136 & 29 \\
\hline Age $22-23$ & 114 & 10 & 151 & 10 & 272 & 13 & 60 & 14 \\
\hline Age 24-25 & 160 & 13 & 244 & 15 & 306 & 14 & 70 & 16 \\
\hline Age $26-29$ & 445 & 34 & 516 & 34 & 558 & 27 & 109 & 26 \\
\hline Age $30-34$ & 269 & 24 & 275 & 22 & 400 & 18 & 67 & 13 \\
\hline Age 35 and older & 66 & 12 & 73 & 10 & 75 & 5 & 8 & 2 \\
\hline \multicolumn{9}{|l|}{ Education } \\
\hline Low & 221 & 22 & 252 & 18 & 339 & 16 & 36 & 6 \\
\hline Medium & 364 & 40 & 659 & 51 & 1,118 & 58 & 278 & 71 \\
\hline High & 564 & 38 & 491 & 31 & 605 & 26 & 136 & 22 \\
\hline \multicolumn{9}{|l|}{ Union status } \\
\hline Single & 51 & 11 & 61 & 10 & 79 & 12 & 34 & 20 \\
\hline Ongoing union & 1,030 & 83 & 1,248 & 85 & 1,750 & 77 & 317 & 67 \\
\hline New union & 68 & 7 & 93 & 5 & 233 & 11 & 99 & 14 \\
\hline \multicolumn{9}{|l|}{ Gender } \\
\hline Male & 525 & 44 & 611 & 47 & 736 & 37 & 178 & 38 \\
\hline Female & 624 & 56 & 791 & 53 & 1326 & 63 & 272 & 62 \\
\hline Total & 1,149 & 100 & 1,402 & 100 & 2,062 & 100 & 450 & 100 \\
\hline
\end{tabular}


Table 2: $\quad$ (Continued)

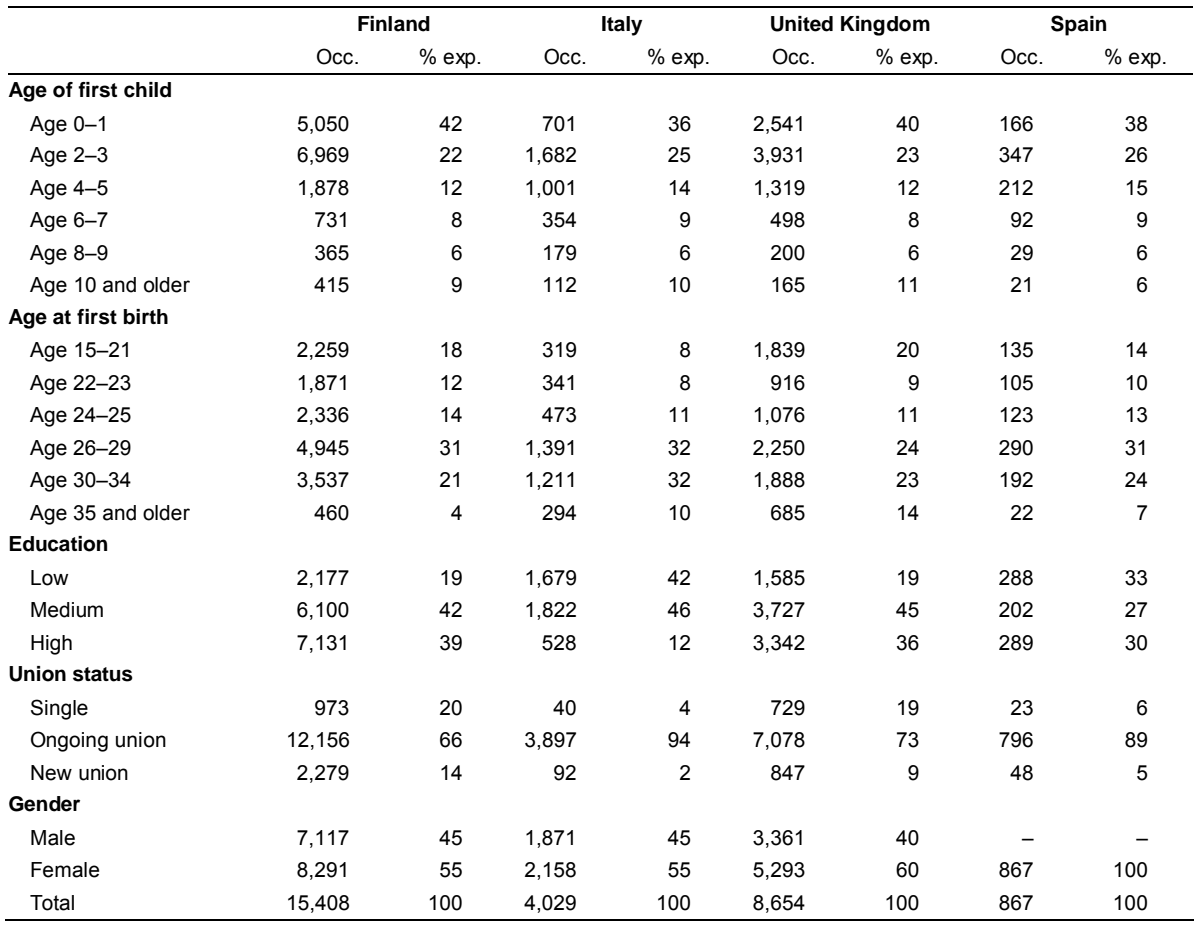

\section{Results}

\subsection{Separation and birth spacing}

Table 3 displays the mean difference between first and second births by whether the second child is with a new parent or not. For individuals who stay partnered with the parent of the first child, it is about three years. There is some country variation, with Finland and Belgium displaying very narrow birth intervals of less than three years on average. For the other countries, mean differences between the first two births are around or a bit higher than three years. Italy and eastern Germany are notable exceptions in this comparison, with a mean age difference between first and second children of more than four years. For all countries, separation leads to increased birth intervals; compared to people in ongoing unions, the duration between first and second children is about one and a half times to twice as long. People who had either the first 
or the second child as a single person hold an intermediate position. They space their births wider apart than couples who remain partnered to the parent of the firstborn child. However, on average they space their births closer than people who have a second child in a new union.

Table 3: Mean difference between first and second children in years (standard error in parenthesis), only women and men who had at least two children at interview

\begin{tabular}{lcccc}
\hline & $\begin{array}{c}\text { First and second children in } \\
\text { same union }\end{array}$ & \multicolumn{2}{c}{$\begin{array}{c}\text { First and second children } \\
\text { in different unions }\end{array}$} \\
& All & Single births & New union & All \\
\hline Belgium & 2.78 & 3.55 & 6.90 & 5.46 \\
Finland & $(0.05)$ & $(0.42)$ & $(0.41)$ & $(0.33)$ \\
& 2.84 & 4.18 & 5.17 & 4.88 \\
France & $(0.02)$ & $(0.11)$ & $(0.07)$ & $(0.06)$ \\
& 3.18 & 3.93 & 5.49 & 4.98 \\
Germany (western) & $(0.45)$ & $(0.38)$ & $(0.27)$ & $(0.23)$ \\
& 3.27 & 4.46 & 6.60 & 6.07 \\
Germany (eastern) & $(0.05)$ & $(0.50)$ & $(0.42)$ & $(0.35)$ \\
& 4.07 & 4.80 & 6.43 & 6.19 \\
Italy & $(0.19)$ & $(0.56)$ & $(0.48)$ & $(0.38)$ \\
& 4.08 & 4.19 & 6.43 & 5.80 \\
Spain & $(0.04)$ & $(0.53)$ & $(0.41)$ & $(0.35)$ \\
& 3.87 & 3.38 & 5.44 & 4.84 \\
United Kingdom & $(0.09)$ & $(0.43)$ & $(0.41)$ & $(0.34)$ \\
& 2.99 & 3.88 & 5.59 & 4.88 \\
& $(0.02)$ & $(0.11)$ & $(0.12)$ & $(0.09)$ \\
\hline
\end{tabular}

Notes: The sample includes women and men who had their first child in 1990 or later. For Germany only cohorts born 1971-1973 and for Finland only cohorts born 1969-1972 were selected for this representation. The Spanish sample includes women only. Results for Belgium, Germany, and France were weighted.

These simple descriptive statistics as presented in Table 3 are calculated for respondents who had at least two children, and they do not account for possible censoring. Because our focus of analysis is on recent birth behavior, this aspect is of utmost concern, as many of the more recent cohorts may separate or have a second child after the time of interview. A more appropriate method that takes censoring into account makes use of the cumulative incidence curves as displayed in Figure 1. These give the probability of having a second child depending on whether the second child is in an ongoing union or not. Note that single births are grouped under "new union" here.

Figure 1 reveals large differences in the likelihood that second children are in a new union. In Finland, a large proportion of second children are born in a new union. Among the people who have a second child, almost $20 \%$ had this second child in a new union ten years after the first birth. In Germany and the United Kingdom, the likelihood of having a second child in a new union is lower. But even in these countries a substantial proportion of the population have their first two children in different unions 
(assumed to be with different partners). For Germany, behavior in the eastern and western parts of the country differs greatly. Multi-partnered fertility is much more common in eastern than in western Germany. For Belgium and France, despite a high progression rate to the second child in general, the likelihood of having a second child with a new partner is low. Apparently, couples usually have a second child before separation. Spain and Italy stand apart from the rest of Europe. In these two Southern European countries, the likelihood of having a second child is lower than elsewhere, and the likelihood of having a second child in a new union is negligible.

Figure 1: Cumulative incidence functions, outcome variables:

1) second child in ongoing union, 2) second child in new union (including single births)
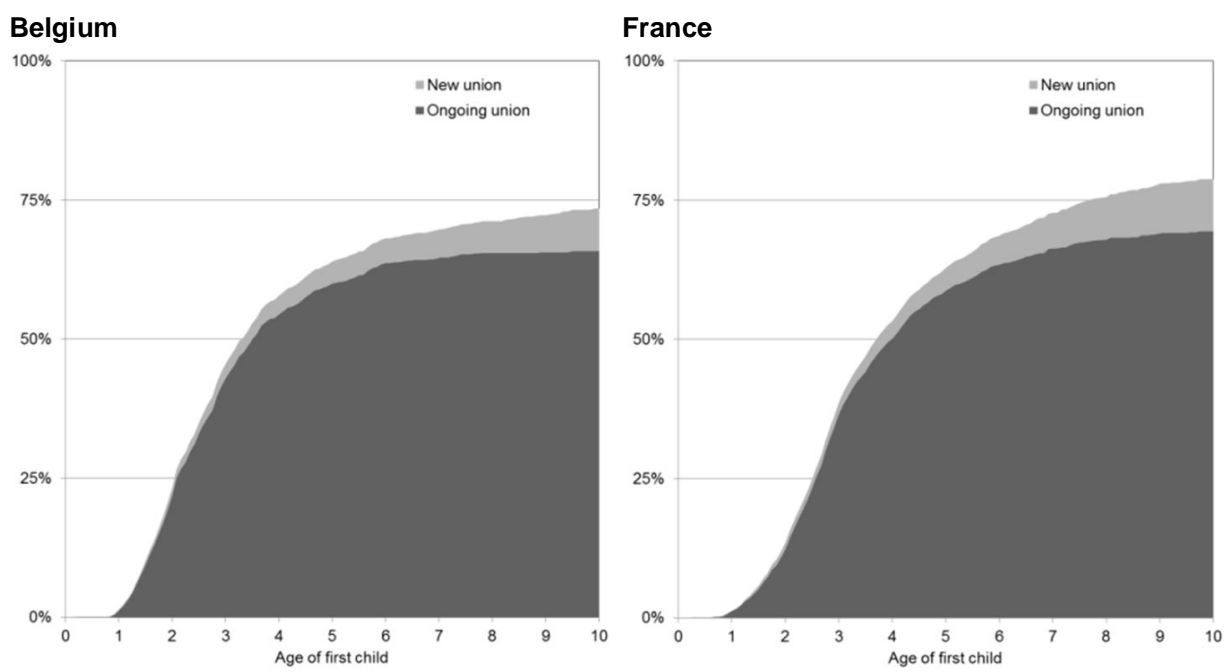
Kreyenfeld et al:: Social policies, separation, and second birth spacing in Western Europe

Figure 1: (Continued)



\section{Finland}

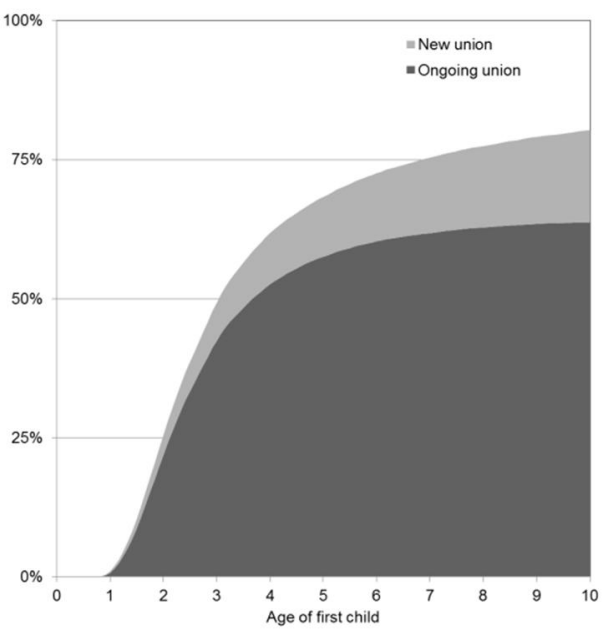

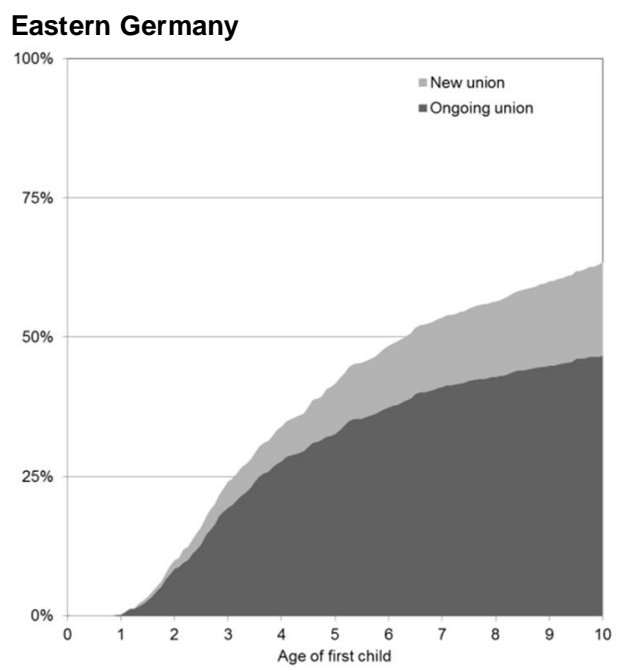

United Kingdom

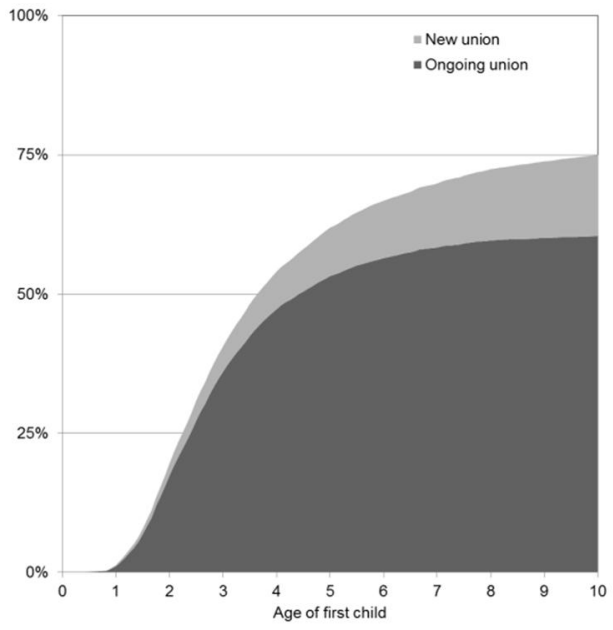


Figure 1: (Continued)
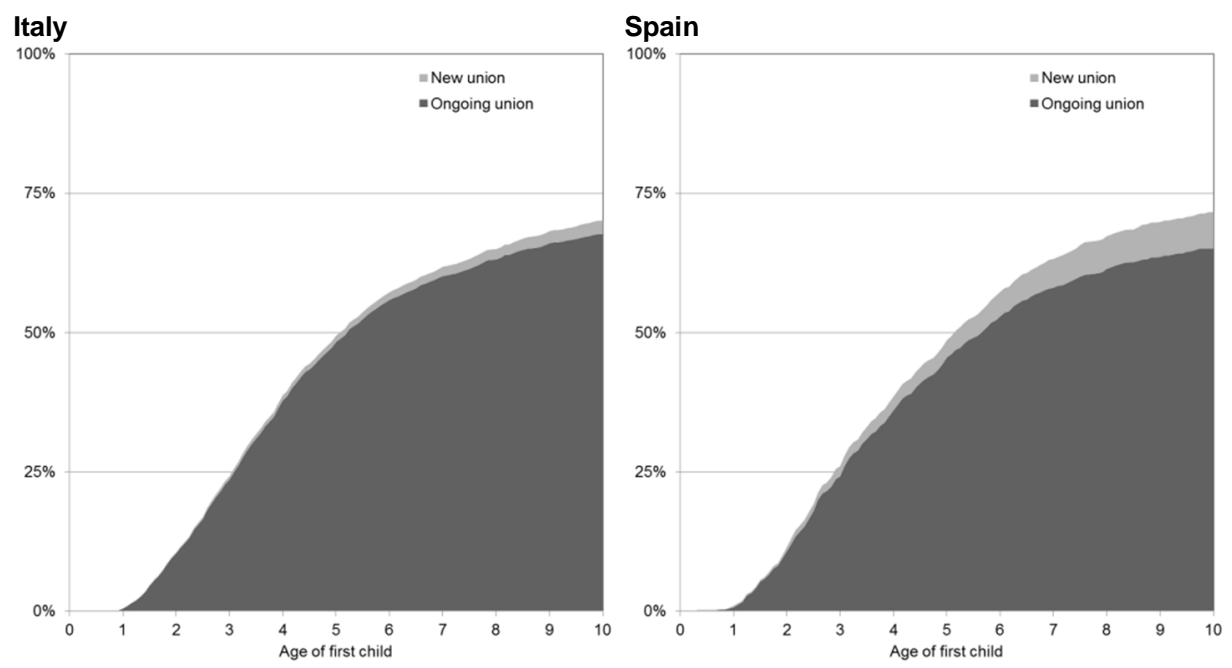

Notes: The sample includes women and men who had their first child in 1990 or later. For Germany only cohorts born 1971-1973 and for Finland only cohorts born 1969-1972 were selected for this representation. The Spanish sample includes women only. Results for Belgium, Germany, and France were weighted.

\subsection{Multivariate results}

The descriptive analysis has revealed large differences in the probability of having a second child in a new union across Europe. However, we have not yet accounted for the different chances of entering a new union. In the next step, we investigate the rate of having a second child by union status. In order to address this issue, we employ a multivariate analysis by estimating an event history model. The event of interest is second birth. The main process time is the duration since last birth. The baseline intensity is modeled with a piecewise constant specification. Together with standard control variables, such as education, sex, age at first birth, and child's age, we account for the union status.

The results are presented in Table 4. The control variables follow an expected pattern. We find that second birth rates decline with increasing age at first birth. Furthermore, for most of the countries we find that high education increases second birth rates, which is compatible with prior findings on second birth fertility in Western European countries (e.g., Kravdal 2001). The key variable in our model is the union status. In most countries, we do not find significant or large differences between individuals in ongoing and new unions. This also holds for Spain and Italy. In the 
descriptive statistics, we have shown that second births in a new union are rather uncommon in Spain and Italy. Based on the multivariate analysis, we may conclude that the low prevalence of postseparation fertility in these countries is not due to the low risk of having a second child in a new union, but rather to the low chances of entering a new union after first birth. Once people enter a new union, second birth rates are comparable to those of couples in ongoing unions, even in these countries. In Finland, hazard rates for couples in new unions and in ongoing unions are almost the same. The case that stands apart from the rest is eastern Germany. Here we find significantly elevated second birth risks in a new union. For people in a new union, second birth risks increase by $47 \%$ compared to people in an ongoing union. This result mirrors those of prior studies, showing a high degree of family diversity in eastern Germany (Kreyenfeld, Konietzka, and Heintz-Martin 2016). Although Germany is a familialistic regime, eastern Germans behave more like Finns, for whom separation and divorce are not a great hindrance to entering a new partnership and having a child with a new partner.

Table 4: Results from piecewise constant event history model: Relative risks of second birth

\begin{tabular}{|c|c|c|c|c|c|c|c|c|}
\hline & Belgium & France & $\begin{array}{l}\text { Western } \\
\text { Germany }\end{array}$ & $\begin{array}{l}\text { Eastern } \\
\text { Germany }\end{array}$ & Finland & $\begin{array}{c}\text { United } \\
\text { Kingdom }\end{array}$ & Italy & Spain \\
\hline \multicolumn{9}{|l|}{ Age at first birth } \\
\hline Age 15-21 & 1 & 1 & 1 & 1 & 1 & 1 & 1 & 1 \\
\hline Age $22-23$ & 0.78 & 0.94 & 1.00 & 0.91 & $0.96^{* *}$ & $0.90^{\star \star \star *}$ & 0.98 & 1.04 \\
\hline Age $24-25$ & $0.78^{*}$ & 0.95 & 1.03 & 0.92 & $0.94^{* * *}$ & $0.85^{\star \star \star}$ & 0.99 & 1.03 \\
\hline Age $26-29$ & $0.76^{\star \star}$ & $0.83^{*}$ & 0.91 & 0.80 & $0.88^{* * *}$ & $0.82^{\star \star \star}$ & 0.96 & 0.94 \\
\hline Age $30-34$ & $0.62^{\star \star *}$ & $0.68^{\star \star \star}$ & 0.90 & 0.83 & $0.76^{* \star \star}$ & $0.72^{\star \star \star}$ & $0.81^{* \star *}$ & $0.80^{*}$ \\
\hline Age 35 and older & $0.31^{\star \star \star}$ & $0.39^{* * *}$ & $0.63^{* \star *}$ & 0.65 & $0.56^{* \star *}$ & $0.44^{\star \star \star}$ & $0.58^{* * *}$ & $0.32^{\star * *}$ \\
\hline \multicolumn{9}{|l|}{ Education } \\
\hline Low & 1 & 1 & 1 & 1 & 1 & 1 & 1 & 1 \\
\hline Medium & 0.88 & 0.87 & 0.88 & $0.67^{\star \star}$ & $1.10^{\star \star \star}$ & $0.92^{\star \star \star}$ & 1.04 & 0.91 \\
\hline High & $1.47^{\star \star \star}$ & 1.17 & 1.10 & 1.05 & $1.28^{* * *}$ & 1.05 & $1.23^{\star \star *}$ & $1.21^{\star *}$ \\
\hline \multicolumn{9}{|l|}{ Union status } \\
\hline Ongoing union & 1 & 1 & 1 & 1 & 1 & 1 & 1 & 1 \\
\hline Single & $0.42^{* \star *}$ & $0.36^{* * *}$ & $0.27^{\text {***}}$ & $0.35^{\star \star \star}$ & $0.30^{* * *}$ & $0.36^{* \star *}$ & $0.24^{\star \star *}$ & $0.36^{\star \star *}$ \\
\hline New union & 1.10 & 1.08 & 0.95 & $1.46^{* \star *}$ & $0.97^{* *}$ & 1.02 & 1.07 & 0.96 \\
\hline
\end{tabular}

Notes: Further control variables in model are age of first child and gender. ${ }^{* *} p<0.01 ;{ }^{* \star} p<0.05 ;{ }^{*} p<0.10$.

\subsection{Transition to second births in new unions (results from interaction models)}

In the last step of our analysis, we investigate socioeconomic differences in the risks of having a second child in a new union. For this purpose we conducted an interaction of union status with level of education. These interaction models are restricted to western 
Germany, the United Kingdom, and Finland, as only these countries provide the sample size for a refined analysis. We focus particularly on educational differences in the progression to a second child. This focus is motivated by prior studies showing large differences in multi-partnered fertility by education, in particular for the United States (Carlson and Furstenberg 2006; Guzzo and Furstenberg 2007a, 2007b; Manlove et al. 2008; Scott et al. 2013; Thomson et al. 2014).

Table 5 displays the results from interaction models. The models were standardized for low education, in order to be able to gauge the educational gradient by union type. The table shows that the risk of having a second child in an ongoing union is positive for all countries. There is a negative educational gradient for single births in the United Kingdom and western Germany, but not in Finland. We also find country differences for the risk of having a second child in a new union. While we find a positive gradient in the case of Finland, there is a negative gradient in western Germany and no educational differences in the United Kingdom. Based on this evidence, we may conclude that the strong educational differences in multi-partnered fertility previously found in the United States do not easily transfer to European countries. At least in the case of second birth fertility, we do not find a consistent and strong negative educational gradient in the risk of having another child with a new partner.

Table 5: Results from piecewise constant event history model. Interaction of union status and education, standardized for low education. Relative risks of second birth

\begin{tabular}{llll}
\hline & Low & Medium & High \\
\hline Western Germany & & & \\
$\quad$ Single & 1 & 0.92 & $0.50^{\star * *}$ \\
$\quad$ Ongoing union & 1 & 0.97 & 1.18 \\
$\quad$ New union & 1 & $0.63^{\star *}$ & 0.79 \\
United Kingdom & & & \\
$\quad$ Single & 1 & $0.74^{\star *}$ & $0.60^{\star * *}$ \\
$\quad$ Ongoing union & 1 & 0.94 & 1.10 \\
$\quad$ New union & 1 & 0.97 & 0.93 \\
Finland & & & \\
$\quad$ Single & 1 & $0.85^{\star * *}$ & 1.00 \\
$\quad$ Ongoing union & 1 & $1.17^{* *}$ & $1.37^{* * *}$ \\
$\quad$ New union & 1 & 1.02 & $1.14^{* * *}$ \\
\hline
\end{tabular}

Notes: Further control variables in model are age of first child, age at first birth, gender. ${ }^{\star \star \star} p<0.01 ;{ }^{* \star} p<0.05 ;{ }^{*} p<0.10$. 


\section{Discussion and limitations}

The aim of this paper was to contribute to the growing literature on multi-partnered fertility. While multi-partnered fertility in the United States has been explored extensively, less is known about the determinants of having children with different partners in Europe. Based on recent survey and register data for Western Europe, we examined progressions to the second child. Our guiding hypothesis was that familialism would result into low postseparation fertility. We indeed find that countries differ radically in the prevalence of postseparation births. However, patterns cannot always be explained by policy contexts. A substantial proportion of second births are in new unions in Germany and the United Kingdom, despite these countries having familialistic regimes. Belgium and France hold only an intermediate position, although they are widely regarded as conducive to the compatibility of work and family and emphasize economic independence before and after divorce. The reason for the relatively low prevalence of postseparation births in France and Belgium is that first and second births are closely spaced so that separation often occurs after the second child is born. In Southern Europe only a negligible proportion of the population have a second child with a new partner. The reason for the low likelihood of having a second child with a new partner in Italy and Spain is the low risk of dissolving a union and entering a new union. Conditional on entering a new union, the patterns for Italy and Spain are similar to those of other countries. This suggests that the low second birth fertility in Southern Europe may be explained by the social and normative barriers that hinder couples from dissolving unsatisfactory unions and entering new partnerships.

For demographic research, our results highlight the importance of union dissolution for fertility behavior. Prior studies have already illuminated the fact that separation and divorce are important to understand differences in national fertility rates. Our paper has more narrowly focused on the spacing of second births. Separation and divorce are not only relevant for understanding differences in higher-order births or total fertility; we have also shown that second birth spacing is greatly affected by separation and divorce, albeit to different degrees in the different countries that we have considered in our investigation.

In contrast to previous research from the United States, we find no consistent negative educational gradient in multi-partnered fertility. One reason may be that we focused on transition rates to the second child, whereas prior analysis often looked into total fertility (Beaujouan and Solaz 2013; Carlson and Furstenberg 2006) or analyzed fertility progressions to the next child in a competing risk framework (Thomson et al. 2014). Furthermore, differences may also stem from the different treatment of births in singlehood and births in unions. In our multivariate analysis, we separated births to single individuals from those to individuals in a new union. For the latter population, 
we find elevated second birth rates for those with less education. Another reason may be that many previous studies focus on the United States. The results from this country may simply not be transferable to the European context.

While the strength of this paper is that it highlights the fact that postseparation policies are of growing importance to understanding family behavior, we must acknowledge that our paper is only a modest step toward a comprehensive understanding of the relationship between social policies, partnership, and fertility behavior after divorce and separation. We have discussed regulations on spousal support in some detail, but many other policies, such as child alimony or child custody, were not addressed in great detail. An important difficulty was also that regulations concerning spousal and child maintenance are only loosely regulated by law and are often defined in individual court cases. In addition, countries differ in how they enforce payments. Most countries have established systems to document childcare policies and parental leave regulations, but comprehensive statistics to document child or spousal support are missing in most countries, let alone comparable statistics at the EU level.

Another great limitation of this paper was the data. We used the more recent largescale family surveys for our investigation. However, we had to make very simplistic assumptions for our investigation to identify multi-partnered fertility, because most of the survey data sets did not provide sufficient information to link children to partnerships. As in previous studies, we assumed here that children are from different partners if the respondent had seen a disruption of the union between first and second births, or was single at first birth and did not move in with a partner within six months of childbirth. This procedure might have greatly overestimated the share of births with a new partner, because living-apart-together arrangements may have been erroneously classified as new partnerships. Conversely, we have dropped unions from our investigation where respondents could not remember the start or end dates of their nonmarital unions or marriages (see code in the online Appendix). These people may be particularly prone to have children with different partners (Kreyenfeld and Bastin 2015), so we may have also underestimated the extent of multi-partnered fertility.

Beyond these obstacles to generating reliable family indicators, small sample sizes kept us from more detailed investigations by population subgroups. Most importantly, we were unable to examine gender differences due to small sample sizes. Prior studies have shown that social policies define the economic well-being of individuals after divorce and separation. The economic consequences of divorce and separation are commonly more severe in familialistic welfare states than in more defamilializing systems, and, most importantly, vary by gender. How the economic conditions that women and men are exposed to in the different countries of Europe vary, and how that affects their partnership and fertility behavior after separation, must be left to future research. 


\section{Acknowledgments}

The research leading to these results received funding from the European Union's Seventh Framework Programme (FP7/2007-2013) under grant agreement no. 320116 for the research project FamiliesAndSocieties. We also acknowledge funds from the Academy of Finland (decision number 275030 and 293103) and the German Science Foundation (KR 2855/3-1 and TR 457/7-1). This paper was presented at the Annual Conference of the Population Association of America (PAA) in San Diego in April 2015 and at the IUSSP-International Seminar "Separation, Divorce, Repartnering and Remarriage around the World" in Montreal in May 2015. We are grateful for the many valuable comments that we received at these meetings. We would particularly like to thank Elizabeth Thomson and Trude Lappegård for their insightful input. For language editing, we are grateful to Renée Lüskow and Lena Klein. Any remaining errors are ours. 


\section{References}

Andreß, H.-J. and Bröckel, M. (2007). Marital disruption in Germany: Does the conservative welfare state care? Changes in material well-being and the effects of private and public transfers. Schmollers Jahrbuch 127(2): 193-226.

Andreß, H.-J., Borgloh, B., Bröckel, M., Giesselmann, M., and Hummelsheim, D. (2006). The economic consequences of partnership dissolution: A comparative analysis of panel studies from Belgium, Germany, Great Britain, Italy, and Sweden. European Sociological Review 22(5): 533-560. doi:10.1093/esr/jcl012.

Beaujouan, É. and Solaz, A. (2013). Racing against the biological clock? Childbearing and sterility among men and women in second unions in France. European Journal of Population 29(1): 39-67. doi:10.1007/s10680-012-9271-4.

Beaujouan, É. and Wiles-Portier, E. (2011). Second-union fertility in France: Partners' age and other factors. Population 66(2): 239-274. doi:10.3917/pope.1102.0239.

Boisson, M. and Wisnia-Weill, V. (2012). Désunion et paternité. Paris: Centre d'analyse stratégique (Note d'analyse, $n^{\circ} 294$ ).

Bröckel, M. and Andreß, H.-J. (2015). The economic consequences of divorce in Germany: What has changed since the turn of the millennium? Comparative Population Studies 40(3): 277-312.

Burkhauser, R.V., Duncan, G.J., Hauser, R., and Berntsen, R. (1991). Wife or frau, women do worse: A comparison of men and women in the United States and Germany after marital dissolution. Demography 28(3): 353-360. doi:10.2307/ 2061461.

Carlson, M.J. and Furstenberg, F. (2006). The prevalence and correlates of multipartnered fertility among urban U.S. parents. Journal of Marriage and Family 68(3): 718-732. doi:10.1111/j.1741-3737.2006.00285.x.

Castles, F.G. (2003). The world turned upside down: Below replacement fertility, changing preferences, and family-friendly public policy in 21 OECD countries. Journal of European Social Policy 13(3): 209-227. doi:10.1177/0958928703 0133001 .

Duvander, A.-Z., Lappegård, T., and Andersson, G. (2010). Family policy and fertility: Fathers' and mothers' use of parental leave and continued childbearing in Norway and Sweden. Journal of European Social Policy 20(1): 45-57. doi:10.1177/0958928709352541. 
Esping-Andersen, G. (1999). Social foundations of postindustrial economies. Oxford: Oxford University Press. doi:10.1093/0198742002.001.0001.

EUROSTAT (2015). Fertility indicators [electronic resource]. Luxembourg: European Commission. http://appsso.eurostat.ec.europa.eu/nui/show.do

Gałęzewska, P. (2016). Repartnering dynamics and fertility in new partnerships in Europe and the United States $[\mathrm{PhD}$ thesis]. Southampton: University of Southampton.

Gauthier, A.H. (2007). The impact of family policies on fertility in industrialized countries: A review of the literature. Population Research Policy Review 26(3): 323-346. doi:10.1007/s11113-007-9033-x.

Gooley, T.A., Leisenring, W., Crowley, J., and Storer, B.E. (1999). Estimation of failure probabilities in the presence of competing risks: New representations of old estimators. Statistics in Medicine 18(6): 695-706. doi:10.1002/(SICI)10970258(19990330)18:6<695::AID-SIM60>3.3.CO;2-F.

Griffith, J.D., Koo, H.P., and Suchindran, C.M. (1985). Childbearing and family in remarriage. Demography 22(1): 73-88. doi:10.2307/2060987.

Guzzo, K. and Furstenberg, F. (2007a). Multipartnered fertility among American men. Demography 44(3) 583-601. doi:10.1353/dem.2007.0027.

Guzzo, K. and Furstenberg, F. (2007b). Multipartnered fertility among young women with a nonmarital first birth: Prevalence and risk factors. Perspectives on Sexual and Reproductive Health 39(1): 29-38. doi:10.1363/3902907.

Hannemann, T. and Kulu, H. (2015). Union formation and dissolution among immigrants and their descendants in the United Kingdom. Demographic Research 33(10): 273-312. doi:10.4054/DemRes.2015.33.10.

Heintz-Martin, V., Le Bourdais, C., and Hamplová, D. (2014). Childbearing among Canadian stepfamilies. Canadian Studies in Population 41(1-2): 61-77. doi:10.25336/P6D89W.

Henz, U. (2002). Childbirth in East and West German stepfamilies: Estimated probabilities from hazard rate models. Demographic Research 7(6): 307-342. doi:10.4054/DemRes.2002.7.6.

Henz, U. and Thomson, E. (2005). Union stability and stepfamily fertility in Austria, Finland, France, and West Germany. European Journal of Population 21(1): $3-$ 29. doi:10.1007/s10680-004-7267-4. 
Hogan, D.P. (1978). The variable order of events in the life course. American Sociological Review 43(4): 573-586. doi:10.2307/2094780.

Holland, J.A. and Thomson, E. (2011). Stepfamily childbearing in Sweden: Quantum and tempo effects, 1950-1999. Population Studies 65(1): 115-128. doi:10.1080/ 00324728.2010 .543693 .

Instituto Nacional de Estadística (INE) (2013). Estadística denulidades, separaciones y divorcios [electronic resource]. Madrid: INEbase. www.ine.es.

ISTAT (2014). Separazioni e divorzi in Italia: Anno 2012 [electronic resource]. Roma: Istituto nazionale di statistica. http://www.istat.it/en/archive/32717.

Kalwij, A. (2010): The impact of family policy expenditure on fertility in western Europe. Demography 47(2): 503-519. doi:10.1353/dem.0.0104.

Kindler, H. and Walper, S. (2016): Das Wechselmodell im Kontext elterlicher Konflikte. Neue Zeitschrift für Familienrecht 3(18): 820-824.

Klett-Davies, M. (2016). Under pressure? Single parents in the U.K. Gütersloh: Bertelsmann Stiftung.

Kravdal, Ø. (1996). How the local supply of day-care centers influences fertility in Norway: A parity-specific approach. Population Research and Policy Review 15(3): 201-218. doi:10.1007/BF00127049.

Kravdal, Ø. (2001). The high fertility of college educated women in Norway: An artefact of the separate modelling of each parity transition. Demographic Research 5(6): 187-215. doi:10.4054/DemRes.2001.5.6.

Kreyenfeld, M. and Bastin, S. (2015): Reliability of union histories in social science surveys: Blurred memory, deliberate misreporting, or true tales? Advances in Life Course Research 27: 30-42. doi:10.1016/j.alcr.2015.11.001.

Kreyenfeld, M., Huinink, J., Trappe, H., and Walke, R. (2012). DemoDiff: A dataset for the study of family change in Eastern (and Western) Germany. Schmollers Jahrbuch 132(4): 653-660. doi:10.3790/schm.132.4.653.

Kreyenfeld, M., Konietzka, D., and Heintz-Martin, V. (2016). Lebens- und Familienformen. In: Niephaus, Y., Kreyenfeld, M., and Sackmann, R. (eds.). Handbuch Bevölkerungssoziologie. Wiesbaden: Springer VS: 303-325.

Kreyenfeld, M. and Martin, V. (2011). Economic conditions of stepfamilies from a cross-national perspective. Zeitschrift für Familienforschung 23(2): 128-153. 
Kulu, H. and Hannemann, T. (2015). Why does fertility remain high among certain United Kingdom-born ethnic minority women? Brussels: European Commission, Socioeconomic Sciences and Humanities (Families and Societies working paper series 39: 67-97).

Lenze, A. (2014). Alleinerziehende unter Druck: Rechtliche Rahmenbedingungen, finanzielle Lage und Reformbedarf. Gütersloh: Bertelsmann Stiftung.

Lauwereys, G., Neels, K., and De Winter, T. (2011). Wave 1: Response rate calculation. The Hague: Generations and Gender Programme (GGP Belgium paper series 3).

Manlove, J., Logan, C., Ikramullah, E., and Holcombe, E. (2008). Factors associated with multiple-partner fertility among fathers. Journal of Marriage and Family 70(2): 536-548. doi:10.1111/j.1741-3737.2008.00499.x.

Martin, V. (2008). Stepfamilies in Canada: Numbers, characteristics, stability, and childbearing $[\mathrm{PhD}$ thesis]. Montreal: McGill University, Department of Sociology.

McDonald, P. (2000). Gender equity, social institutions, and the future of fertility. Journal of Population Research 17(1): 1-16. doi:10.1007/BF03029445.

Meggiolaro, S. and Ongaro, F. (2010). The implications of marital instability for a woman's fertility: Empirical evidence from Italy. Demographic Research 23(34): 963-996. doi:10.4054/DemRes.2010.23.34.

National Institute for Health and Welfare (2016). Child maintenance and custody 2015 [electronic resource]. Helsinki: National Institute for Health and Welfare. http://www.julkari.fi/bitstream/handle/10024/130561/Tr11_16.pdf?sequence=4

Neyer, G. (2003). Family policies and low fertility in Western Europe. Journal of Population and Social Security 1(Suppl.): 46-93.

Ní Bhrolcháin, M. (1986). Women's paid work and the timing of births. Longitudinal evidence. European Journal of Population 2(1): 43-70. doi:10.1007/BF01796 880 .

Ongaro, F., Mazzuco, S., and Meggiolaro, S. (2009). Economic consequences of union dissolution in Italy: Finding from the European Community Household Panel. European Journal of Population 25(1): 45-65. doi:10.1007/s10680-008-9157-7.

Orloff, A.S. (1993). Gender and the social rights of citizenship: The comparative analysis of gender relations and welfare states. American Sociological Review 58(3): 303-328. doi:10.2307/2095903. 
Scott, M., Peterson, K., Ikramullah, E., and Manlove, J. (2013). Multiple partner fertility among unmarried nonresident fathers. In: Cabrera, N. and TamisLeMonda, C. (eds.). Handbook of father involvement: Multidisclinary perspectives. New York: Routledge: 97-115.

Testa, M.R. (2007). Childbearing preferences and family issues in Europe: Evidence from the Eurobarometer 2006 survey. Vienna Yearbook of Population Research 2007: 353-377. doi:10.1553/populationyearbook2007s357.

Thévenon, O. (2011). Family policies in OECD countries: A comparative analysis. Population and Development Review 37(1): 57-87. doi:10.1111/j.1728-4457. 2011.00390.x.

Thomson, E. (2004). Step-families and childbearing desires in Europe. Demographic Research, Special Collection on Contemporary Research on European Fertility: Perspectives and Developments 3(5): 117-134. doi:10.4054/DemRes.2004.S3.5.

Thomson, E., Lappegård, T., Carlson, M., Evans, A., and Gray, E. (2014). Childbearing across partnerships in Australia, the Unites States, Norway, and Sweden. Demography 51(2): 485-508. doi:10.1007/s13524-013-0273-6.

Vergauwen, J., Wood, J., De Wachter, D., and Neels, K. (2015). Quality of demographic data in GGS wave 1. Demographic Research 32(24): 723-774. doi:10.4054/DemRes.2015.32.24.

Vikat, A., Thomson, E., and Hoem, J.M. (1999). Stepfamily fertility in contemporary Sweden: The impact of childbearing before the current union. Population Studies 53(1): 211-225. doi:10.1080/00324720308082.

Vikat, A., Thomson, E., and Prskawetz, A. (2004). Childbearing responsibility and stepfamily fertility in Finland and Austria. European Journal of Population 20(1): 1-21. doi:10.1023/B:EUJP.0000014536.56286.41.

Wood, J. (2016). Essays on socioeconomic differentiation in European fertility: The impact of economic context and social policy [PhD thesis]. Antwerpen: Universiteit Antwerpen. 
Kreyenfeld et al:: Social policies, separation, and second birth spacing in Western Europe

\section{Appendix}

Table A-1: Data description

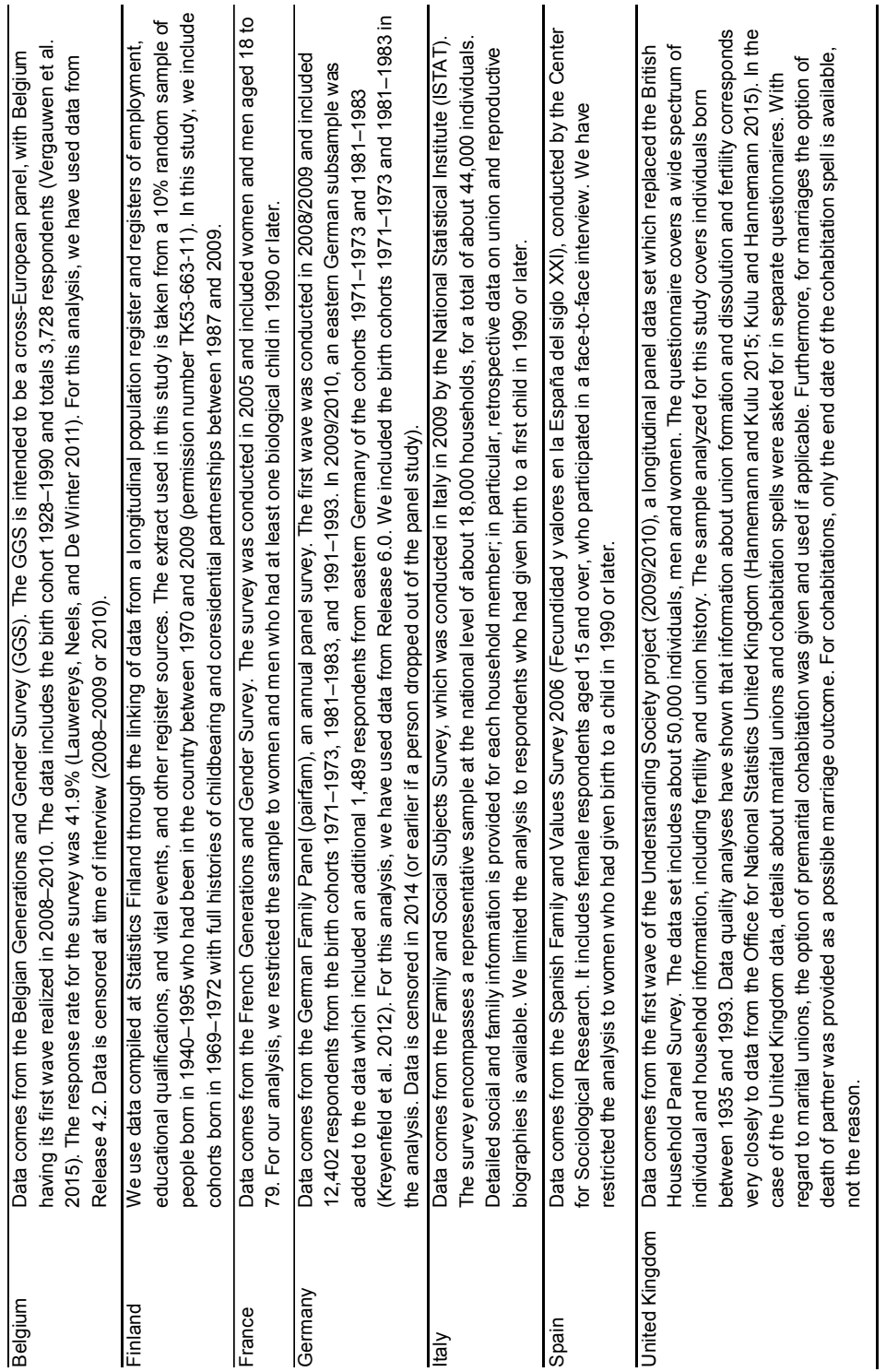


Table A-2: Separation and second birth as competing events, results from cumulative incidence curves

\begin{tabular}{|c|c|c|c|c|c|c|c|c|}
\hline & \multicolumn{2}{|c|}{ Belgium } & \multicolumn{2}{|c|}{ Finland } & \multicolumn{2}{|c|}{ France } & \multicolumn{2}{|c|}{ Germany (western) } \\
\hline & $2^{\text {nd }}$ birth & Separation & $2^{\text {nd }}$ birth & Separation & $2^{\text {nd }}$ birth & Separation & $2^{\text {nd }}$ birth & Separation \\
\hline Age of first child & $0 \%$ & $7 \%$ & $0 \%$ & $14 \%$ & $0 \%$ & $5 \%$ & $0 \%$ & $9 \%$ \\
\hline Age 0 & $61 \%$ & $10 \%$ & $60 \%$ & $20 \%$ & $60 \%$ & $9 \%$ & $58 \%$ & $12 \%$ \\
\hline Age 5 & $68 \%$ & $12 \%$ & $86 \%$ & $21 \%$ & $73 \%$ & $10 \%$ & $70 \%$ & $13 \%$ \\
\hline Age 10 & 1,844 & 1,844 & 20,488 & 20,488 & 2,054 & 2,054 & 2,353 & 2,353 \\
\hline Individuals & 1,070 & 213 & 12,891 & 4,262 & 1,844 & 1,844 & 1,398 & 274 \\
\hline \multirow[t]{3}{*}{ Events } & 1,070 & 213 & 12,891 & 4,262 & 1,844 & 1,844 & 1,398 & 274 \\
\hline & \multicolumn{2}{|c|}{ Germany (eastern) } & \multicolumn{2}{|c|}{ Italy } & \multicolumn{2}{|c|}{ Spain } & \multicolumn{2}{|c|}{ United Kingdom } \\
\hline & $2^{\text {nd }}$ birth & Separation & $2^{\text {nd }}$ birth & Separation & $2^{\text {nd }}$ birth & Separation & $2^{\text {nd }}$ birth & Separation \\
\hline Age of first child & $0 \%$ & $16 \%$ & $0 \%$ & $5 \%$ & $0 \%$ & $8 \%$ & $0 \%$ & $16 \%$ \\
\hline Age 0 & $36 \%$ & $24 \%$ & $48 \%$ & $6 \%$ & $46 \%$ & $9 \%$ & $53 \%$ & $21 \%$ \\
\hline Age 5 & $51 \%$ & $27 \%$ & $67 \%$ & $6 \%$ & $66 \%$ & $9 \%$ & $61 \%$ & $22 \%$ \\
\hline Age 10 & 535 & 535 & 7,028 & 7,028 & 1,666 & 1,666 & 13,576 & 13,576 \\
\hline Individuals & 254 & 142 & 3,876 & 413 & 804 & 138 & 7,140 & 2,886 \\
\hline Events & 254 & 142 & 3,876 & 413 & 804 & 138 & 7,140 & 2,886 \\
\hline
\end{tabular}

Notes: The sample includes women and men who had their first child in 1990 or later. For Germany only cohorts born 1971-1973 and for Finland only cohorts born 1969-1972 were selected for this representation. The Spanish sample includes women only. Results for Belgium, Germany, and France were weighted.

Table A-3: Postseparation regulations on child maintenance, 2000

\begin{tabular}{lccccccc}
\hline & Belgium & Finland & France & Germany & Italy & $\begin{array}{c}\text { Spain } \\
\begin{array}{c}\text { United } \\
\text { Kingdom }\end{array}\end{array}$ \\
\hline $\begin{array}{l}\text { Average child maintenance payment per child } \\
\text { (mean), US\$ PPP }\end{array}$ & 219.70 & 139.50 & 152.40 & 183.60 & n.a. & n.a. & 244.80 \\
$\begin{array}{l}\text { Child maintenance as \% of total income transfers } \\
\begin{array}{l}\text { Percentage of lone parents receiving child } \\
\text { maintenance }\end{array}\end{array}$ & 38.1 & 29.7 & 40.1 & 37.2 & n.a. & n.a. & 40.0 \\
\hline
\end{tabular}

Source: OECD Family Database, table PF1.5.B and table PF1.5.C (estimations based on Luxembourg Income Study). http://www.oecd.org/els/family/database.htm. 
Kreyenfeld et al.: Social policies, separation, and second birth spacing in Western Europe

Table A-4: Postseparation regulations and practice on custody and shared residence

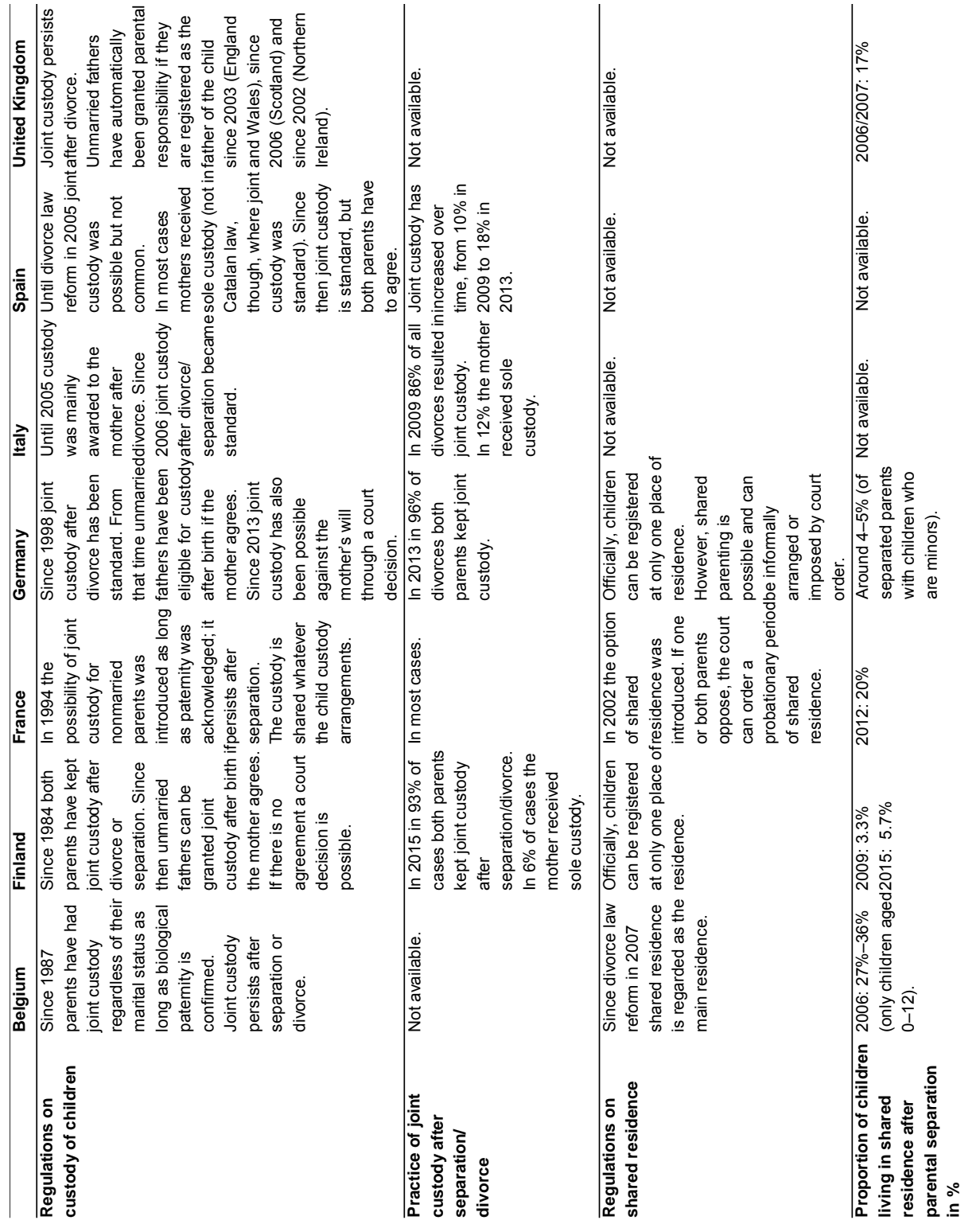

Source: INE (2013); ISTAT (2014); Kindler and Walper (2016); National Institute for Health and Welfare (2016). 